\title{
Flavylium-Based Hypoxia-Responsive Probe for Cancer Cell Imaging
}

\author{
Thitima Pewklang ${ }^{1}$, Sirawit Wet-osot ${ }^{1}{ }^{\mathbb{D}}$, Sirilak Wangngae ${ }^{1}$, Utumporn Ngivprom ${ }^{1}$, Kantapat Chansaenpak ${ }^{2}$, \\ Chuthamat Duangkamol ${ }^{1}$, Rung-Yi Lai ${ }^{1, *}$, Parinya Noisa ${ }^{3}{ }^{1}$, Mongkol Sukwattanasinitt ${ }^{4}$ \\ and Anyanee Kamkaew ${ }^{1, *(1)}$
}

1 School of Chemistry, Institute of Science, Suranaree University of Technology, Nakhon Ratchasima 30000, Thailand; thitima.27.1996@gmail.com (T.P.); sirawitwetosot@gmail.com (S.W.-o.); swsirilak00@gmail.com (S.W.); utumporn_n@kkumail.com (U.N.); chuthamat_duangkamol@hotmail.com (C.D.)

2 National Nanotechnology Center, National Science and Technology Development Agency, Thailand Science Park, Pathum Thani 12120, Thailand; kantapat.cha@nanotec.or.th

3 Laboratory of Cell-Based Assays and Innovations, Institute of Agricultural Technology, School of Biotechnology, Suranaree University of Technology, Nakhon Ratchasima 30000, Thailand; p.noisa@sut.ac.th

4 Thailand Nanotec-CU Center of Excellence on Food and Agriculture, Department of Chemistry, Faculty of Science, Chulalongkorn University, Bangkok 10330, Thailand; mongkol.s@chula.ac.th

* Correspondence: rylai@sut.ac.th (R.-Y.L.); anyanee@sut.ac.th (A.K.)

check for updates

Citation: Pewklang, T.; Wet-osot, S.; Wangngae, S.; Ngivprom, U.; Chansaenpak, K.; Duangkamol, C.;

Lai, R.-Y.; Noisa, P.; Sukwattanasinitt, M.; Kamkaew, A. Flavylium-Based Hypoxia-Responsive Probe for Cancer Cell Imaging. Molecules 2021, 26, 4938. https://doi.org/10.3390/ molecules26164938

Academic Editor: Peter Verwilst

Received: 1 July 2021

Accepted: 11 August 2021

Published: 15 August 2021

Publisher's Note: MDPI stays neutral with regard to jurisdictional claims in published maps and institutional affiliations.

Copyright: (c) 2021 by the authors. Licensee MDPI, Basel, Switzerland. This article is an open access article distributed under the terms and conditions of the Creative Commons Attribution (CC BY) license (https:// creativecommons.org/licenses/by/ $4.0 /)$.

\begin{abstract}
A hypoxia-responsive probe based on a flavylium dye containing an azo group (AZO-Flav) was synthesized to detect hypoxic conditions via a reductase-catalyzed reaction in cancer cells. In in vitro enzymatic investigation, the azo group of AZO-Flav was reduced by a reductase in the presence of reduced nicotinamide adenine dinucleotide phosphate (NADPH) followed by fragmentation to generate a fluorescent molecule, Flav- $\mathrm{NH}_{2}$. The response of AZO-Flav to the reductase was as fast as $2 \mathrm{~min}$ with a limit of detection (LOD) of $0.4 \mu \mathrm{M}$. Moreover, AZO-Flav displayed high enzyme specificity even in the presence of high concentrations of biological interferences, such as reducing agents and biothiols. Therefore, AZO-Flav was tested to detect hypoxic and normoxic environments in cancer cells (HepG2). Compared to the normal condition, the fluorescence intensity in hypoxic conditions increased about 10-fold after $15 \mathrm{~min}$. Prolonged incubation showed a 26-fold higher fluorescent intensity after $60 \mathrm{~min}$. In addition, the fluorescence signal under hypoxia can be suppressed by an electron transport process inhibitor, diphenyliodonium chloride (DPIC), suggesting that reductases take part in the azo group reduction of AZO-Flav in a hypoxic environment. Therefore, this probe showed great potential application toward in vivo hypoxia detection.
\end{abstract}

Keywords: flavylium; azo dye; hypoxia detection; turn-on fluorescent sensor; activity-based sensing

\section{Introduction}

Solid tumor growth is restricted by vascularization, which requires oxygen and nutrient supply. It has been reported that the median oxygen concentration is around $4 \%$ in some solid tumors and can be decreased to as low as $0 \%$ in a certain area [1,2]. Such low oxygen conditions in tumors are known as hypoxia, which is primarily due to variations in microcirculation and temporary disturbance in oxygen perfusion [3]. Tumor hypoxia usually occurs at a distance of 100-200 $\mu \mathrm{m}$ from blood vessels and seems to be strongly associated with tumor propagation, malignant progression and resistance to chemo- and radiotherapy $[4,5]$. Hypoxia could regulate the expression of several genes by the stabilization of hypoxia-inducible factor $1 \alpha(\mathrm{HIF}-1 \alpha)$, leading to various biological phenomena [6]. Thus, the detection of hypoxia is an important approach to investigate its biological effects.

In the past decade, several activity-based fluorescent probes for hypoxia sensing have been developed and tested in living cells [7-10]. Various functional groups, such as aromatic nitro, azo, and quinone groups, were reported as hypoxia-sensitive moieties; their 
signaling mechanisms rely on a photoinduced electron transfer (PeT) [11]. However, most of these probes are photo-unstable, have low selectivity, and are susceptible to the $\mathrm{pH}$ or polarity of the media $[1,12,13]$. Hence, a better chemical- and photo-stable probe with high selectivity and sensitivity is still required to be developed for hypoxia detection.

Compared to the normal environment, many endogenous cytochrome P450 enzymes are highly expressed in hypoxic locations [12]. Therefore, many prodrugs were designed to be activated by oxidation and catalyzed by cytochrome P450 enzymes [13-16]. Moreover, due to the activation of cytochrome $\mathrm{P} 450$ enzymes requiring reductases to transfer electrons to reduce their iron centers, cytochrome $\mathrm{P} 450$ reductases are also more present in cancer cells than normal cells [17]. Hence, cytochrome P450 reductases are alternative targets in cancer research $[18,19]$. Since cytochrome P450 reductases catalyze electron transfer to activate cytochrome $\mathrm{P} 450$ enzymes, few functional groups susceptible to reduction have been applied in probe design $[20,21]$. Notably, the azo aromatic compounds were reported to be good substrates for cytochrome P450 reductases and some azo-containing fluorescent probes displayed effective results in hypoxia detection $[7,22-24]$.

In this study, we designed an azo-flavylium probe to detect cancer cells, because flavylium structures could be derivatized to possess interesting photophysical properties $[25,26]$. For example, a flavylium structure was modified to contain a nitroaromatic ring for the detection of nitroreductase activity in living cells by observing its ratiometric fluorescence changes [27]. A similar strategy was applied on the flavylium design to probe hydrogen polysulfide $\left(\mathrm{H}_{2} \mathrm{~S}_{n}\right)$, which reduced the nitroaromatic group of the probe to the corresponding amino group showing 87-fold fluorescence enhancement [28]. However, there has been no attempt to incorporate an azo moiety in a flavylium dye for controllable fluorescent off/on switching for hypoxia detection. Therefore, we designed and synthesized a flavylium dye containing an azo group (AZO-Flav) as a fluorescent turn-on probe for hypoxia response in cancer cells. The characterization of AZO-Flav showed negligible fluorescence due to the azo entity, a photoisomerizable quenching unit. However, after the reductase-catalyzed reaction the fluorescence was distinctively enhanced. This is because the azo group was reduced followed by the elimination of 4-dimethylaminoaniline to generate the fluorescent molecule, Flav- $\mathbf{N H}_{\mathbf{2}}$ (Scheme 1). Furthermore, the probe displayed favorable photophysical properties, excellent stability, and high selectivity toward hypoxia detection. Lastly, AZO-Flav was applied to detect cancer cells (HepG2) in hypoxic conditions compared with normoxic conditions.

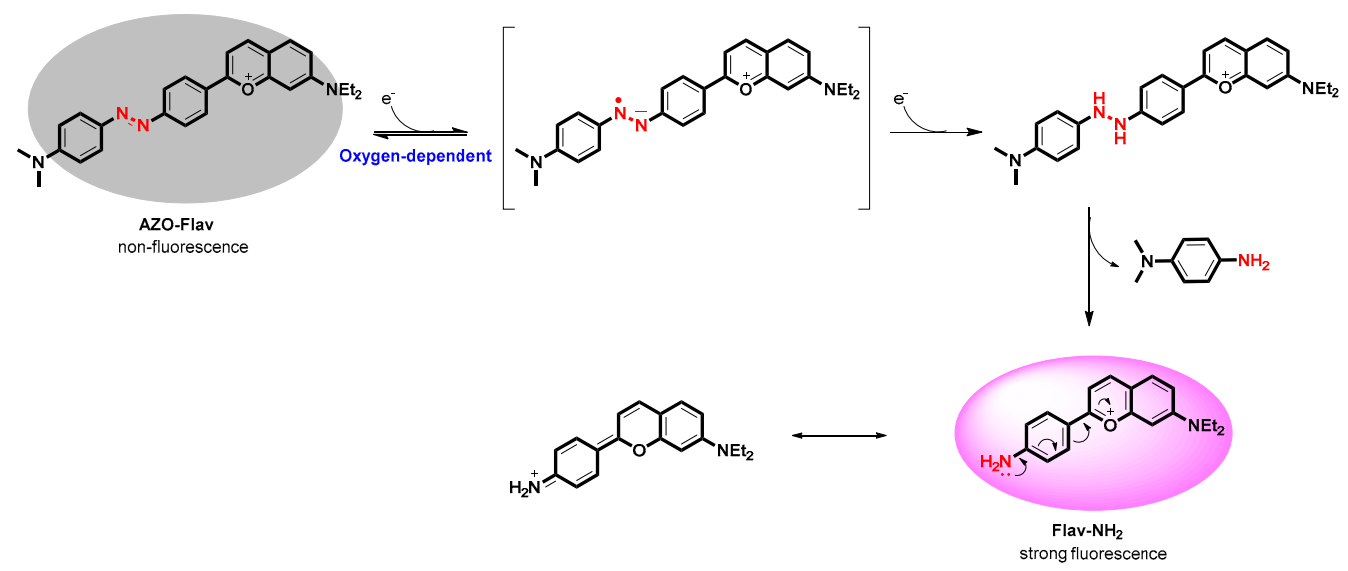

Scheme 1. Proposed activation mechanism of AZO-Flav reduced by a reductase under hypoxia conditions in this work.

\section{Results and Discussion}

\subsection{Probe Synthesis and Characterization}

To develop an activity-based fluorescent probe for hypoxia detection, the key is to incorporate a specific reactive unit. In our design, we integrated an azo group into the 
flavylium skeleton as a reactive unit for reductase-catalyzed reduction. Furthermore, the incorporation of an azo group was aimed to block the dye's fluorescence. In general, the spectroscopic properties of azobenzene have been reported to be a non-fluorogenic compound due to ultrafast isomerization of the azo bond $(-\mathrm{N}=\mathrm{N}-)$ after photoexcitation $[29,30]$. Therefore, we hypothesized that after cleavage of the azo unit, the fluorescence of the flavylium dye would be restored.

A novel azo-flavylium dye (AZO-Flav) was synthesized according to Scheme 2. First, the azo dye 1 was obtained through the diazotization reaction of 4 -aminoacetophenone and $\mathrm{N}, \mathrm{N}$-dimethylaniline. Next, the condensation between the azo dye $\mathbf{1}$ and 4-(diethylamino)salicylaldehyde under acid conditions generated the corresponding product, AZO-Flav, in a yield of $90 \%$. In addition, the proposed product, Flav- $\mathbf{N H}_{2}$, in Scheme 1 was synthesized according to the literature [31]. The detailed synthesis and characterization of AZO-flav and Flav- $\mathbf{N H}_{2}$ are presented in the Supporting Information.<smiles>CCNc1ccc2ccc(-c3ccc(N=C(C)C)cc3)cc2c1</smiles>

Scheme 2. Synthetic scheme for AZO-Flav; (a) $3 \mathrm{M} \mathrm{HCl}, \mathrm{NaNO}_{2}, \mathrm{AcOH}, 0{ }^{\circ} \mathrm{C}, 2 \mathrm{~h}$. (b) 4-(diethylamino)-salicylaldehyde, $\mathrm{H}_{2} \mathrm{SO}_{4}, 90^{\circ} \mathrm{C}, 2 \mathrm{~h}$.

\subsection{Photophysical Properties of Probe AZO-Flav and Fluorophore Flav-NH}

The photophysical properties of the azo probe, AZO-Flav, and the flavylium fluorophore, Flav- $\mathbf{N H}_{2}$, were investigated to confirm the alteration of the fluorescence process after the fluorophore incorporated with the azo group. The UV-Vis-NIR absorption and fluorescent emission spectra of AZO-Flav and Flav- $\mathbf{N H}_{\mathbf{2}}(10 \mu \mathrm{M})$ in $100 \mathrm{mM}$ phosphate buffer (pH 7.4) are shown in Figure 1. AZO-Flav displays a broader absorption peaking around $570 \mathrm{~nm}$ while Flav- $\mathbf{N H}_{\mathbf{2}}$ exhibits narrower absorption band peaking around $560 \mathrm{~nm}$. In their emission profiles, negligible fluorescence was observed from AZO-Flav due to the depletion of absorbed energy by isomerization of the azo bond in which a similar phenomenon occurred in the reported azo-containing dyes [11]. On the other hand, the flavylium fluorophore (Flav- $\mathbf{N H}_{\mathbf{2}}$ ) displays strong fluorescence peaking at $607 \mathrm{~nm}$, which is also concentration dependent (Figure S1). These emission profiles showed the great difference of emission intensities between AZO-Flav and Flav- $\mathbf{N H}_{\mathbf{2}}$. Therefore, Flav- $\mathbf{N H}_{\mathbf{2}}$ generated from AZO-Flav reduction (Scheme 1) could be an excellent turn-on indicator for hypoxia detection.

\subsection{Fluorescence Stability towards $p H$ Changes}

To ensure our probe can effectively detect the oxygen deficiency area in a tumor, the $\mathrm{pH}$ sensitivities of AZO-Flav and Flav- $\mathbf{N H}_{\mathbf{2}}$ were tested and monitored by fluorescence spectroscopy. The results showed that the fluorescence signals of the reduction product (Flav- $\mathbf{N H}_{2}$ ) were quite stable in the acidic to neutral $\mathrm{pH}$ range $(\mathrm{pH} 3-7)$, whereas the emission intensity dropped about $10-20 \%$ in the basic solution ( $\mathrm{pH} 8-11)$. On the other hand, AZO-Flav still showed low fluorescence signals in $\mathrm{pH}$ ranging from 3 to 11 (Figure 2 and Figure S2), implying no cleavage of the azo bond by altering the $\mathrm{pH}$. These results suggested that the probe AZO-Flav could be stable in hypoxic zones, which are usually acidic [32]. Moreover, the product (Flav- $\mathbf{N H}_{\mathbf{2}}$ ) from the reduction reaction could still maintain its full fluorescent intensity in acidic condition. 


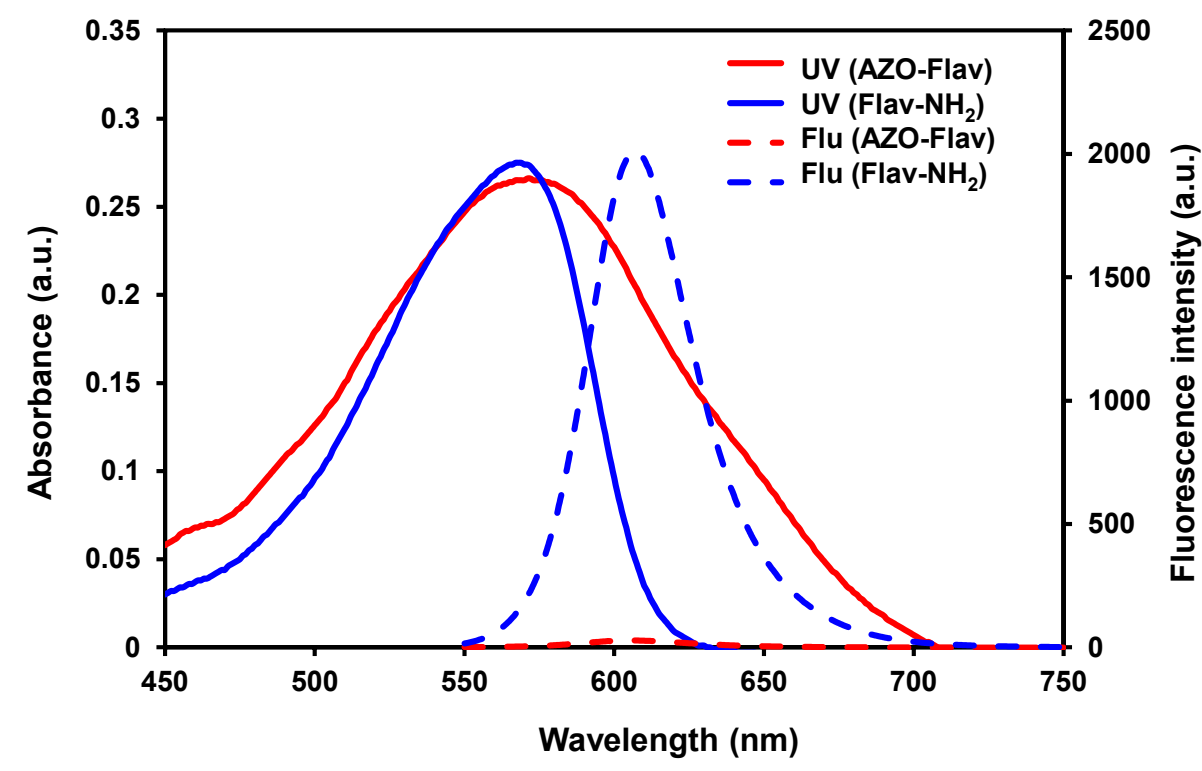

Figure 1. UV-vis-NIR absorption and fluorescence spectra of AZO-Flav and Flav- $\mathbf{N H}_{\mathbf{2}}(10 \mu \mathrm{M})$ in $100 \mathrm{mM}$ phosphate buffer ( $\mathrm{pH} 7.4$ ) excited at $540 \mathrm{~nm}$.

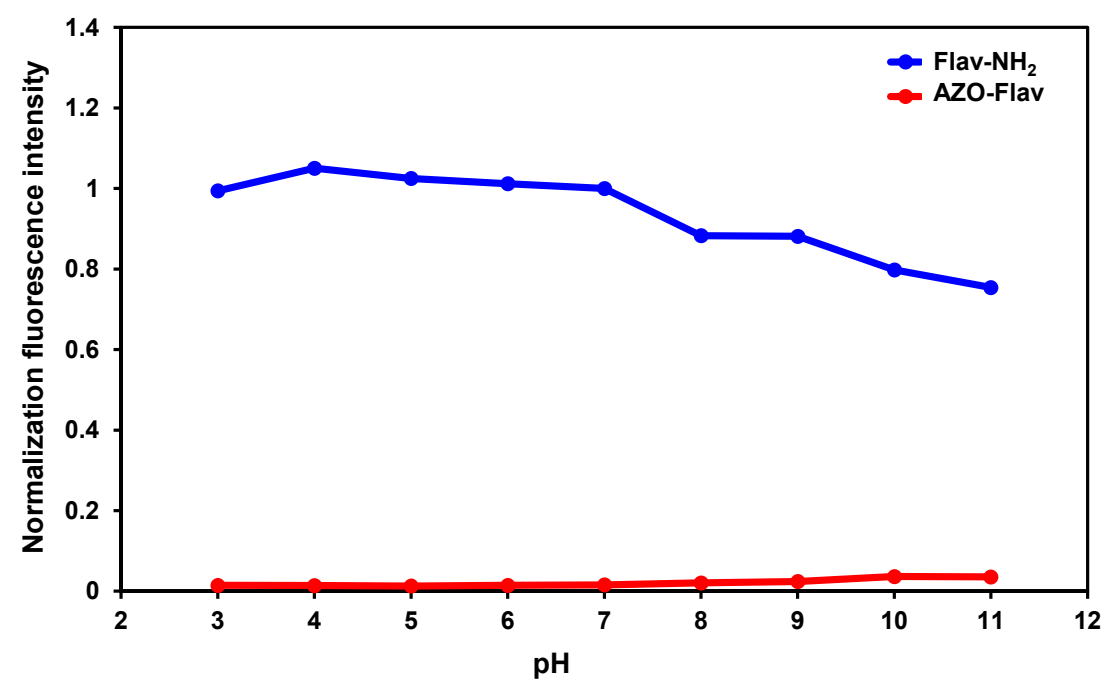

Figure 2. Fluorescent response of AZO-Flav and Flav- $\mathbf{N H}_{2}(10 \mu \mathrm{M})$ at different $\mathrm{pH}$ values $\left(\lambda_{\mathrm{ex}}=540 \mathrm{~nm}\right.$ and $\left.\lambda_{\mathrm{em}}=607 \mathrm{~nm}\right)$.

\subsection{In Vitro Reduction of AZO-Flav by E. coli Flavodoxin Reductase (EcFldR)}

To investigate the ability of the probe AZO-Flav to detect hypoxia, the fluorescence response of AZO-Flav towards reductases was tested in vitro (Figure 3). The flavodoxin reductase, E. coli FldR (EcFldR), was chosen because it can be simply overexpressed and purified in a large quantity in the lab (Figure S3). Moreover, EcFldR has also been applied to reduce various cytochrome P450 enzymes, including microsomal cytochrome P450, via an electron transfer process [33-35]. Therefore, EcFldR could be used to mimic cytochrome P450 reductases in cancer cells. A hypoxic environment was created by purging nitrogen gas for $30 \mathrm{~min}$ before adding EcFldR $(2 \mu \mathrm{M})$ and its cofactor NADPH $(50 \mu \mathrm{M})$. Subsequently, the mixture was preincubated at $37^{\circ} \mathrm{C}$ for $5 \mathrm{~min}$ to activate the enzyme prior to the addition of AZO-Flav $(10 \mu \mathrm{M})$. Upon the addition of AZO-Flav, a dramatic fluorescent enhancement (Figure 3) was detected; its fluorescent spectrum is similar to that of Flav- $\mathbf{N H}_{\mathbf{2}}$. As proposed in Scheme 1, it suggested that the azo bond was cleaved followed by fragmentation to generate Flav- $\mathbf{N H}_{2}$. To further confirm the product identity, the reaction mixture was analyzed by HPLC with the standard comigration (Figure S4). In Figure 3, the control 
reaction (no $E c$ FldR, blue line) did not show fluorescence enhancement, suggesting that Flav- $\mathbf{N H}_{2}$ was resulted from the EcFldR-catalyzed reaction. Furthermore, to confirm that $E c$ FldR catalyzes reduction via electron transfer, which is similar to cytochrome P450 reductases, an experiment for inhibition of the reduction process was performed. Therefore, diphenyliodonium chloride (DPIC), known as an electron scavenger in the electron transport process [36-38], was applied to this study. DPIC was added to the mixture prior to the addition of AZO-Flav, and its inhibitory effect on the EcFldR activity was investigated. We found that the addition of DPIC $(50 \mu \mathrm{M})$ in the full reaction led to a very weak fluorescence signal (Figure 3, green line) similar to the ones of the negative control reactions. This suggested that the electron transfer reduction (Scheme 1) was inhibited. In addition, the coenzyme NADPH was also proved to be a key factor in the EcFldR-catalyzed reduction (Figure 3, magenta line).

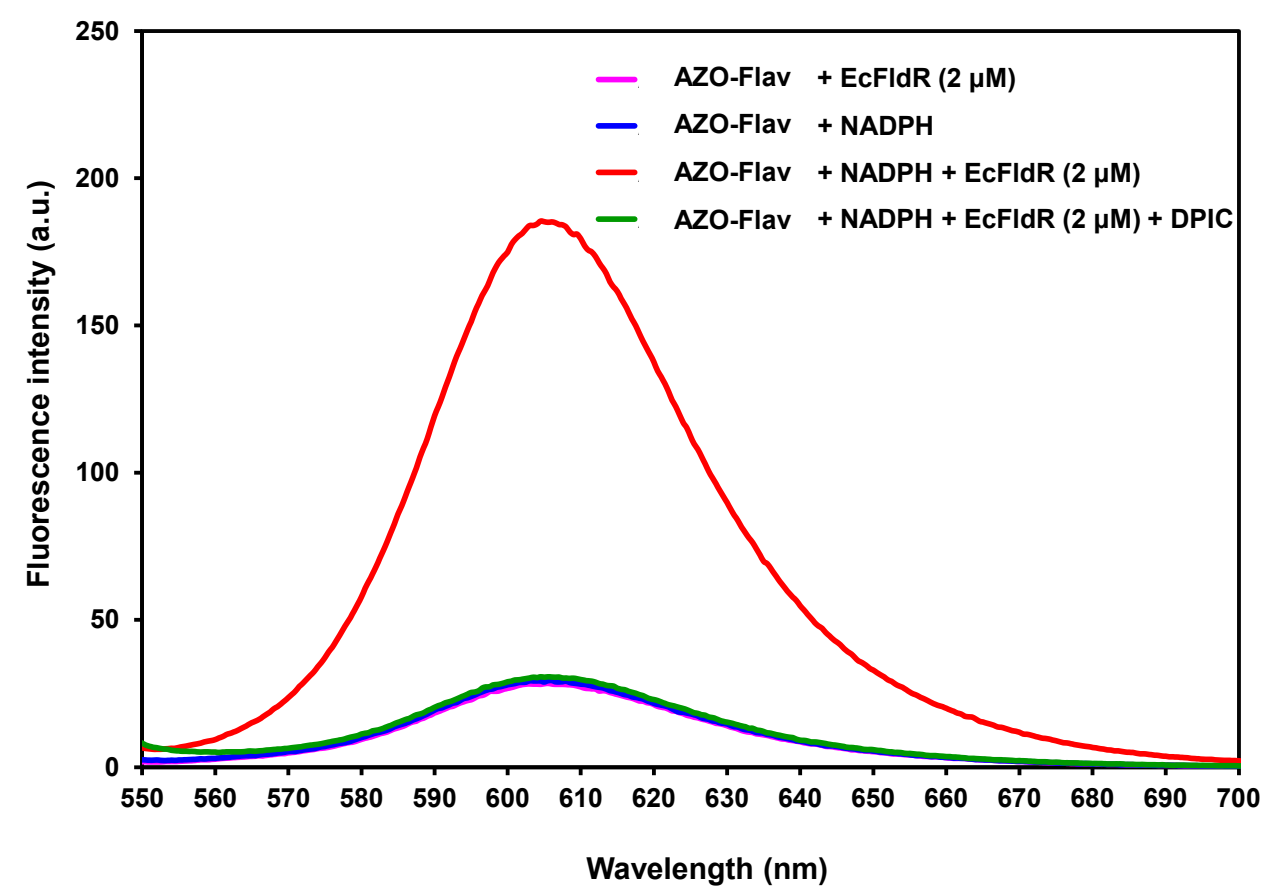

Figure 3. The fluorescent response of AZO-Flav $(10 \mu \mathrm{M})$ in the presence of NADPH $(50 \mu \mathrm{M})$ catalyzed by EcFldR in $100 \mathrm{mM}$ hypoxic phosphate buffer ( $\mathrm{pH} 7.4)$ with and without DPIC $(50 \mu \mathrm{M})$. The spectra were measured at the excitation wavelength of $540 \mathrm{~nm}$.

To mimic sensing of cytochrome P450 reductases in cancer cells, linear fluorescence responses with varied concentrations of AZO-Flav or $E c$ FldR were investigated to monitor the release of Flav- $\mathrm{NH}_{2}$ from AZO-Flav triggered by $E_{c}$ FldR in the presence of excess NADPH by fluorescence spectroscopy (Figure 4). In Figure 4A, the results showed that the fluorescence intensities increased along with AZO-Flav concentration in the presence of a fixed concentration of $E_{c} F l d R$ and excess NADPH. Furthermore, the fluorescence signals reached the maximum after $2 \mathrm{~min}$, which provides the basis for rapid response detection. Moreover, in all experiments, the fluorescence signals of the reduction product $\left(\mathbf{F l a v}-\mathbf{N H}_{\mathbf{2}}\right)$ were higher than the background signals from AZO-Flav at $0 \mathrm{~min}$. To determine the limit of detection (LOD) for EcFldR, $10 \mu \mathrm{M}$ of AZO-Flav and $50 \mu \mathrm{M}$ of NADPH were incubated with varied concentrations of EcFldR $(0-5 \mu \mathrm{M})$ for 2 min and analyzed by fluorescence spectroscopy (Figure 4B). The results showed that the fluorescence intensities linearly increased along with $E c$ FldR concentration $(0-2 \mu \mathrm{M})$. Therefore, the LOD value was calculated to be $0.4 \mu \mathrm{M}$. 

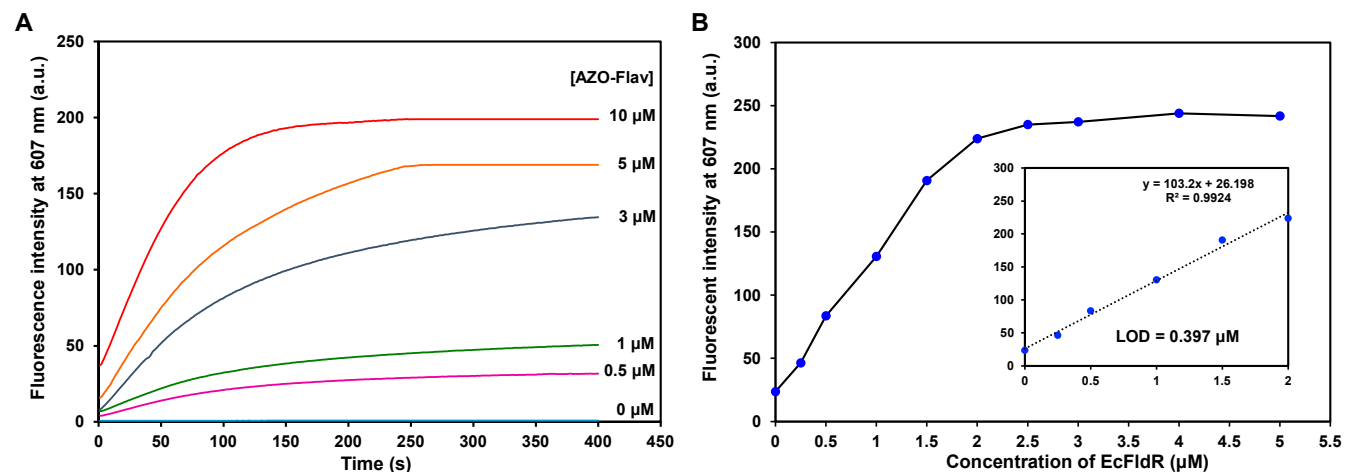

Figure 4. Response of AZO-Flav towards EcFldR under simulated hypoxic conditions. (A) $400 \mathrm{~s}$ time course measurement $\left(\lambda_{\mathrm{ex}}=540 \mathrm{~nm}\right.$ and $\left.\lambda_{\mathrm{em}}=607 \mathrm{~nm}\right)$ of $2 \mu \mathrm{M}$ of EcFldR and $50 \mu \mathrm{M}$ of NADPH incubated with AZO-Flav at various concentrations $(0-10 \mu \mathrm{M})$. (B) AZO-Flav $(10 \mu \mathrm{M})$ responses to various concentrations of $E c F l d R(0.5-5.0 \mu \mathrm{M})$ in the presence of NADPH $(50 \mu \mathrm{M})$.

\subsection{Specificity of AZO-Flav Reduction}

Because cells contain various metabolites and proteins, we investigated whether they react with AZO-Flav to generate false-positive fluorescence signals. AZO-Flav was treated with various reductants (sulfide, sulfite, bisulfite, sodium ascorbate, glutathione, and NADPH), biothiol (cysteine), oxidative species (nitric oxide and hydrogen peroxide), bovine serum albumin (BSA), or glucose. As displayed in Figure 5, all substances in very high concentrations did not induce any noticeable fluorescence enhancement compared with the full reaction (NADPH+EcFldR). Moreover, to be applicable for live cell imaging, AZO-Flav was also tested in the cell lysate extract. Interestingly, there was a turn-on signal in the cell lysate extract experiment. By adding the electron scavenger, DPIC, we could further confirm that the turn-on signal was majorly from the reduction catalyzed by the reductases inside the cells (Figure 5). To be certain that AZO-Flav could be a great candidate for hypoxia detection in tumor environment with high specificity, the following cell assays were performed.

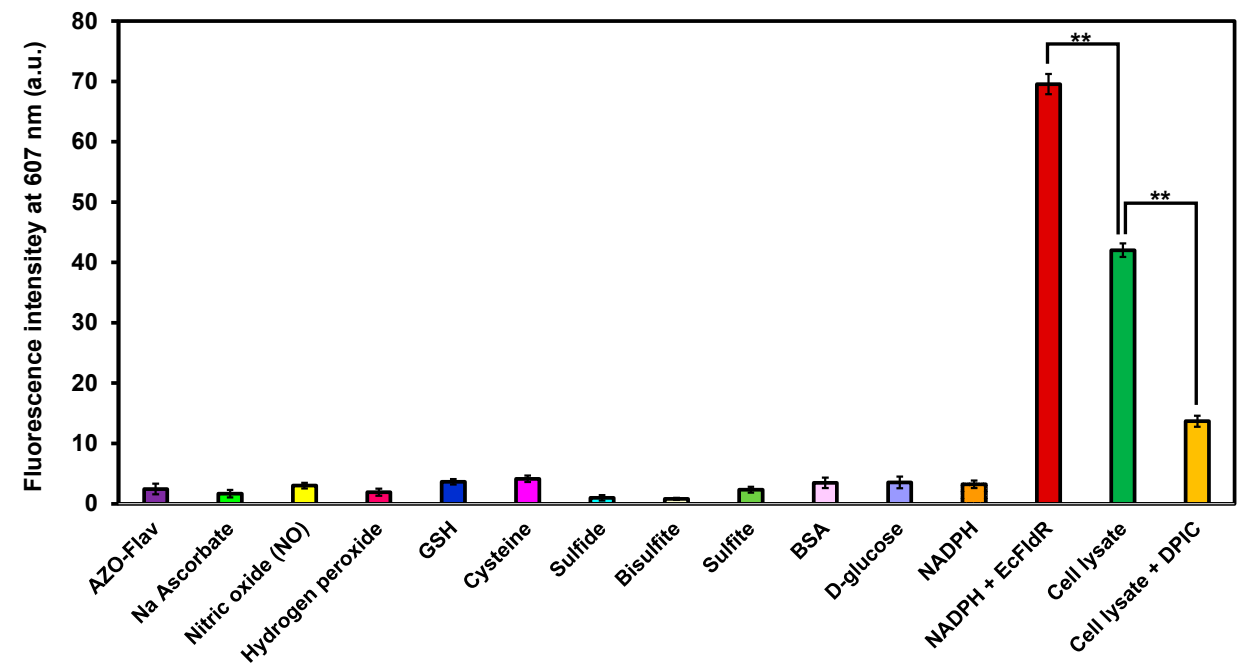

Figure 5. Selectivity of AZO-flav $(10 \mu \mathrm{M})$ towards EcFldR incubated in $100 \mathrm{mM}$ hypoxic phosphate buffer ( $\mathrm{pH} 7.4)$ containing NADPH $(50 \mu \mathrm{M})$ and either $\mathrm{Na}$ ascorbate $(1 \mathrm{mM})$, nitric oxide $(100 \mu \mathrm{M})$, hydrogen peroxide $(100 \mu \mathrm{M}), \mathrm{GSH}(10 \mathrm{mM})$, cysteine $(1 \mathrm{mM})$, sulfide $(1 \mathrm{mM})$, bisulfite $(1 \mathrm{mM})$, sulfite $(1 \mathrm{mM})$, BSA $\left(1 \mathrm{mg} \mathrm{mL}^{-1}\right), D$-glucose $(1 \mathrm{mM}), \mathrm{NADPH}(100 \mu \mathrm{M})$, HepG2 cell lysate extract, or HepG2 cell lysate extract with DPIC compared with AZO-Flav (10 $\mu \mathrm{M})$ alone without enzyme. All samples were incubated for $5 \mathrm{~min}$ at $37^{\circ} \mathrm{C}$ before measuring fluorescent spectra (excitation wavelength $=540 \mathrm{~nm}$ ). Statistical analysis is based on T-test $(* * p<0.01)$. 


\subsection{Hypoxic Cell Imaging}

As all above findings support the potential of AZO-Flav in hypoxia detection, the probe, AZO-Flav, was then applied to monitor the hypoxic condition in human liver carcinoma cells, HepG2. Prior to performing cellular sensing experiments, cytotoxicities of the azo probe, AZO-Flav, and its reduction product, Flav- $\mathbf{N H}_{2}$, were inspected. Cell viability assays using MTT reagent were conducted to determine their safe doses for the live cell detection experiments. The results showed that the cells maintained full viability at concentrations up to $20 \mu \mathrm{M}$ for both AZO-Flav and Flav- $\mathbf{N H}_{\mathbf{2}}$ (Figure S5). At higher concentrations ( $30-50 \mu \mathrm{M})$, cell viability decreased to about $65 \%$. Therefore, the optimal concentration ranges for monitoring hypoxia in cells would be 2.5 to $20 \mu \mathrm{M}$.

Consequently, AZO-Flav was tested in detection of hypoxia in living cells. The HepG2 cells were incubated in a hypoxia incubator chamber $\left(5 \% \mathrm{pO}_{2}\right)$ for different duration times to detect graded hypoxic conditions. It was found that the fluorescent signal of the reduction product was clearly observed after the cells were exposed to the low oxygen condition for $6 \mathrm{~h}$ and reached the maximum after $12 \mathrm{~h}$ incubation (Figure 6A). Therefore, we chose to expose the cells to hypoxia for $12 \mathrm{~h}$ for the following experiments.

\section{A}

AZO-Flav exposure to hypoxia condition
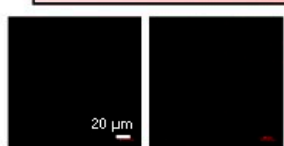

1

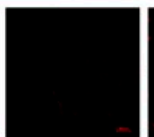

3

3 time (h)

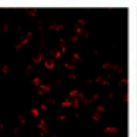

6

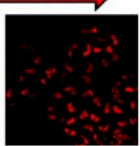

12
B
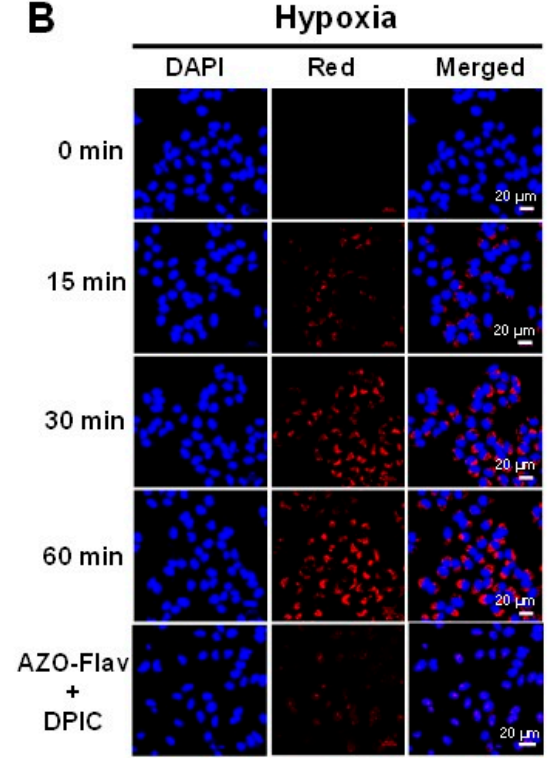

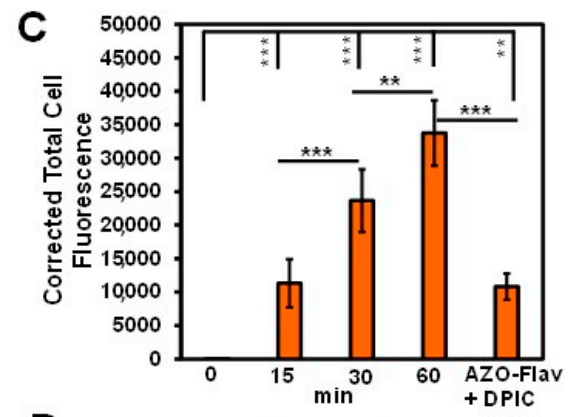

D

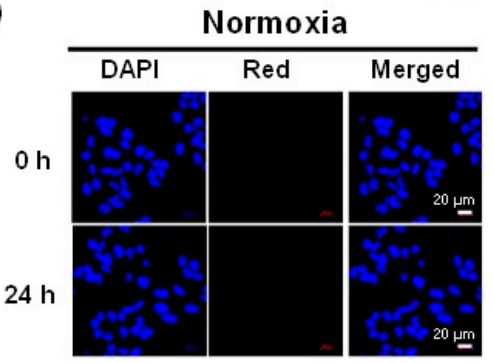

Figure 6. Confocal images of HepG2 cells. (A) Different exposure times (0, 1, 3, 6, and $12 \mathrm{~h}$ ) of HepG2 cells in hypoxic conditions. (B) Time dependent hypoxia detection, with hypoxic cells incubated with $5 \mu \mathrm{M}$ of AZO-Flav for $0,15,30$, and $60 \mathrm{~min}$. DPIC $(50 \mu \mathrm{M})$ was added after $60 \mathrm{~min}$ incubation to inhibit electron transfer. (C) Quantitative corrected total cell fluorescence data of images in B were quantified using ImageJ and represent the mean $\pm \mathrm{SD}(\mathrm{n}=100$ from three independent experiments). (D) The cells incubated with $5 \mu \mathrm{M}$ of AZO-Flav for 0 and $24 \mathrm{~h}$ under normoxia. Statistical analysis: One-way ANOVA followed by Tukey's post-hoc analysis was used for comparison between multiple groups using R studio. P values of less than 0.05 are considered significant $\left({ }^{* *} p<0.01\right.$, $\left.{ }^{* * *} p<0.001\right)$.

After incubation in a hypoxia incubator chamber for $12 \mathrm{~h}$, the cells were treated with AZO-Flav for different time durations $(15,30$, and $60 \mathrm{~min})$. The fluorescence signal of the 
reduction product (Flav- $\mathbf{N H}_{2}$ ) was found to notably increase over time compared to the signal observed from the cells in normoxic conditions (Figure 6B,C, and the Supporting Video). Moreover, the fluorescence from the enzymatic reaction in hypoxia is comparable with the signal observed from the cells incubated with Flav- $\mathbf{N H}_{\mathbf{2}}$ at the same periods (Figure S5). These confirmed that the detected fluorescence signal appeared in a time-dependent manner. In addition, when hypoxic enzyme activity was inhibited by DPIC [7], the fluorescence signal from the cells in the hypoxic environment was suppressed (Figure 6B,C). In contrast, there is no red fluorescent signal observed in normoxic cells, even after incubating with the probe for $24 \mathrm{~h}$ (Figure 6D). To observe if photobleaching occurs after hypoxic cells were incubated with AZO-Flav for 60 min where the maximal signal is achieved, a video of live cell imaging from 60-120 min was recorded to see if the fluorescence remains stable over time. We found that the signal slightly increased over time, and after $90 \mathrm{~min}$ the signal decreased. This implied that the fluorescence from the reduction product is stable for up to 90 min in hypoxic cells (see Supporting Video). Therefore, AZO-Flav was shown to be a highly specific probe for hypoxia detection in living cells.

Dose-dependent internalizations of AZO-Flav and Flav- $\mathrm{NH}_{2}$ were also investigated for comparison. As shown in Figure 7, when greater concentrations of AZO-Flav and Flav- $\mathbf{N H}_{2}$ were used, the fluorescence signals also increased significantly under hypoxic conditions. Interestingly, at higher concentrations $(10-20 \mu \mathrm{M})$, the detected signal of Flav$\mathbf{N H}_{\mathbf{2}}$ was found to be localized in the cell nuclei (Hoechst 33342 signal in blue, DAPI channel). This is in good agreement with previous literature reports regarding the observed interaction of flavylium cations with double-stranded DNA and RNA [39,40]. Moreover, at lower concentrations $(\leq 10 \mu \mathrm{M})$, the reduction product was found to be localized in some organelles such as lysosomes, Golgi apparatus, and mitochondria with Pearson's coefficients of $0.60,0.62$, and 0.55 , respectively (Figure S7).

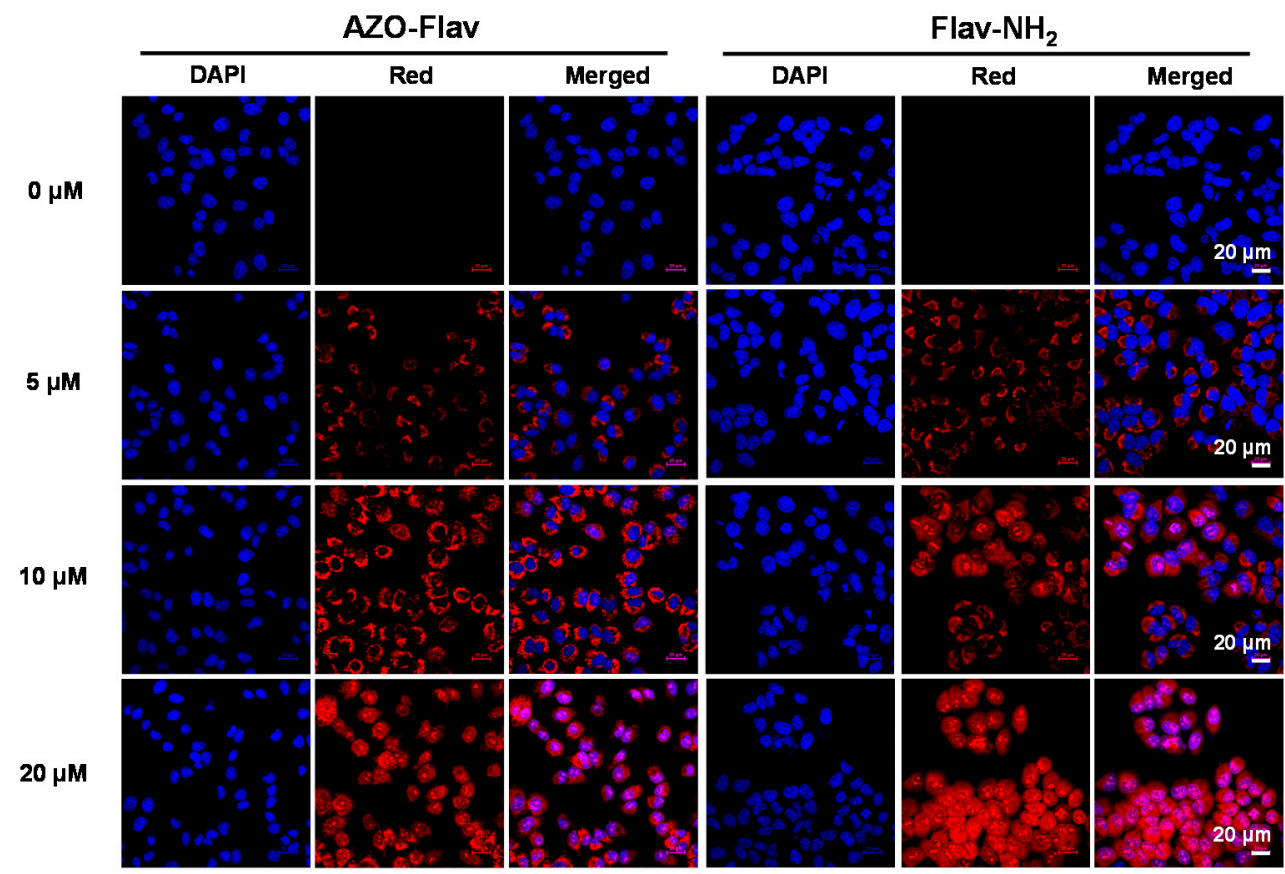

Figure 7. Dose-dependent cellular uptake of AZO-Flav and Flav- $\mathbf{N H}_{2}$ at different concentrations $(0$, 5,10 , and $20 \mu \mathrm{M}$ ) incubated for 60 min under hypoxia.

Finally, to compare AZO-Flav with commercially available hypoxia detection probes such as EF5 [41] and BioTracker 520 Green Hypoxia Dye [22], we list their comparison in Table S1. The key advantages of AZO-Flav are (i) convenient synthesis with less steps and (ii) longer emission wavelength which could avoid signals from cell auto-fluorescence. In addition, AZO-Flav, which is an activity-based sensor probe, shows superior advantages, 
including higher sensitivity, ease of synthesis, and improved selectivity, when compared to some protein-based sensors [42] (Table S2). Moreover, our AZO-Flav showed the fastest detection of reductase activity among other azo-based fluorescent sensors [1,7-9,22,24,43-47] (Table S3). Thus, all experiments ssupport the generation of strongly emissive Flav- $\mathbf{N H}_{\mathbf{2}}$ when AZO-Flav was in the hypoxic environment, confirming its ability of hypoxia detection in cancer cells.

\section{Materials and Methods}

\subsection{Instruments and Chemicals}

For all reactions, glassware was oven-dried prior to use. All reagents were purchased from commercial sources (TCI, Carlo Erba, and Sigma-Aldrich, Milan, Italy) and used without any further purification. Column chromatography purification was performed on a silica gel (Merck, Germany) as a stationary phase. Analytical thin layer chromatography (TLC) was performed on TLC Silica gel 60 F254 (Merck, Germany) and visualized in a UV cabinet $(254$ and $365 \mathrm{~nm}) .{ }^{1} \mathrm{H}$ and ${ }^{13} \mathrm{C}-\mathrm{NMR}$ spectra were recorded on a Bruker-500 MHz spectrometer at room temperature. Chemical shifts of ${ }^{1} \mathrm{H}-\mathrm{NMR}$ spectra were reported in ppm and calibrated from the residual non-deuterated solvent DMSO- $d_{6}(2.50 \mathrm{ppm})$. ${ }^{1} \mathrm{H}-\mathrm{NMR}$ data are reported as the following: chemical shift, multiplicity ( $\mathrm{s}=$ singlet, $\mathrm{d}$ = doublet, $\mathrm{t}=$ triplet, $\mathrm{q}=$ quartet, $\mathrm{m}=$ multiplet), coupling constants, and number of protons. ${ }^{13} \mathrm{C}-\mathrm{NMR}$ spectra were also recorded in ppm, DMSO- $d_{6}$ (39.50 ppm). Mass spectra (MS) were measured under high resolution ESI conditions.

\subsection{Synthesis of AZO-Flav and Flav- $\mathrm{NH}_{2}$}

The detailed syntheses of AZO-Flav and Flav- $\mathbf{N H}_{2}$ are reported in the Supporting Information.

\subsection{Spectroscopic Materials and Methods}

All UV/vis absorption and fluorescence spectra were recorded on a UV-vis spectrophotometer (T80+ UV/vis spectrometer, PG Instruments Ltd., Lutterworth, UK) and a spectrofluorometer (JASCO FP-8300), respectively, and performed in a quartz cell with $1 \mathrm{~cm}$ path length. In all experiments, the stock solutions $(1 \mathrm{mM})$ of AZO-Flav and Flav-NH were prepared in DMSO. Hypoxic phosphate buffer $(100 \mathrm{mM}, \mathrm{pH} 7.4)$ was prepared by $\mathrm{N}_{2}$ purge for $30 \mathrm{~min}$ before measurement. The fluorescence spectra of AZO-Flav and Flav- $\mathbf{N H}_{2}(10 \mu \mathrm{M})$ in $100 \mathrm{mM}$ hypoxic phosphate buffer were recorded with $\lambda_{\mathrm{ex}}=540 \mathrm{~nm}$.

The Study of $\mathrm{pH}$ Effect

The fluorescence response of AZO-Flav and Flav- $\mathbf{N H}_{2}(10 \mu \mathrm{M})$ toward different $\mathrm{pH}$ values was performed in $100 \mathrm{mM}$ buffer at different $\mathrm{pH}$ values $(\mathrm{pH}=3,4,5,6,7,8,9,10$, and 11) and measured at $\lambda_{\mathrm{ex}}=540 \mathrm{~nm}$.

\subsection{EcFld Reductase Assay}

3.4.1. Overexpression and Purification of Escherichia coli Flavodoxin Reductase (EcFldR) Plasmid Construction of pET30-EcFldR

The gene encoding EcFldR was amplified from E. coli MG1655 genomic DNA by Q5 high-fidelity DNA polymerase (New England Biolabs). The plasmid of pET30-EcFldR was constructed by Gibson assembly of PCR products. The amino acid sequence of overexpressed EcFldR contains a N-terminal His-tag and EcFldR (underlined label).

MSSHHHHHHSSGENLYFQGGGMADWVTGKVTKVQNWTDALFSLTVHAPVLPF TAGQFTKLGLEIDGERVQRAYSYVNSPDNPDLEFYLVTVPDGKLSPRLAALKPGDEVQV VSEAAGFFVLDEVPHCETLWMLATGTAIGPYLSILQLGKDLDRFKNLVLVHAARYAADL SYLPLMQELEKRYEGKLRIQTVVSRETAAGSLTGRIPALIESGELESTIGLPMNKETSHVM LCGNPQMVRDTQQLLKETRQMTKHLRRRPGHMTAEHYW. 


\section{Overexpression and Purification of EcFldR}

Ten milliliters of overnight culture of E. coli BL21(DE3) containing pET30-EcFldR was inoculated into $1 \mathrm{~L}$ of Luria-Bertani broth (LB) with $50 \mu \mathrm{g} / \mathrm{mL}$ kanamycin. The culture was shaken at $200 \mathrm{rpm}$ and $37{ }^{\circ} \mathrm{C}$ until $\mathrm{OD}_{600}$ reached about 0.6. Protein expression was induced by addition of isopropyl- $\beta-D$-1-thiogalactopyranoside (IPTG) with a final concentration of $200 \mu \mathrm{M}$. The culture mixture was shaken for an additional $16 \mathrm{~h}$ at $200 \mathrm{rpm}$ and $20{ }^{\circ} \mathrm{C}$. Subsequently, cells were collected by centrifugation $\left(5000 \mathrm{rpm}, 25 \mathrm{~min}, 8{ }^{\circ} \mathrm{C}\right)$ and kept at $-80^{\circ} \mathrm{C}$ till purification. The harvested cells were thawed and resuspended in the lysis buffer ( $300 \mathrm{mM} \mathrm{NaCl}, 50 \mathrm{mM} \mathrm{NaH} \mathrm{PO}_{4}$, and $10 \mathrm{mM}$ imidazole). The cells were lysed by sonication ( $1.5 \mathrm{~s}$ cycle, $50 \%$ duty) on ice, followed by centrifugation at $12,000 \mathrm{rpm}$ and $4{ }^{\circ} \mathrm{C}$ for $40 \mathrm{~min}$. The supernatant was loaded onto a Ni-NTA column (QIAGEN) and the proteins were eluted by the manufacturer's instructions. After elution, the pure fractions were combined and concentrated, followed by incubation with $1 \mathrm{mM}$ of flavin adenine dinucleotide (FAD). The unbound FAD was removed by a 10DG column (BioRad) pre-equilibrated with $100 \mathrm{mM}$ Tris- $\mathrm{HCl}, 30 \%$ glycerol, $\mathrm{pH}$ 7.5. The purified protein was aliquoted and stored at $-80^{\circ} \mathrm{C}$. The SDS-PAGE analysis is showed in Figure S2.

\subsubsection{Response towards EcFld Reductase}

$2 \mu \mathrm{M}$ of $E c$ FldR and $50 \mu \mathrm{M}$ of NADPH were preincubated at $37^{\circ} \mathrm{C}$ for $5 \mathrm{~min}$ in $100 \mathrm{mM}$ hypoxic phosphate buffer ( $\mathrm{pH} 7.4$ ). The reaction was initiated by the addition of $10 \mu \mathrm{M}$ of AZO-Flav and analyzed by fluorescence spectrometry at $\lambda_{\mathrm{ex}}=540 \mathrm{~nm}$ and $\lambda_{\mathrm{em}}=607 \mathrm{~nm}$.

\subsubsection{Selectivity towards EcFld Reductase}

All interference stocks (sodium ascorbate, nitric oxide (NO), hydrogen peroxide $\left(\mathrm{H}_{2} \mathrm{O}_{2}\right)$, glutathione (GSH), cysteine, $\mathrm{Na}_{2} \mathrm{~S}\left(\mathrm{H}_{2} \mathrm{~S}\right), \mathrm{Na}_{2} \mathrm{O}_{5} \mathrm{~S}_{2}\left(\mathrm{HSO}_{3}{ }^{-}\right), \mathrm{Na}_{2} \mathrm{SO}_{3}$, bovine serum albumin (BSA), D-glucose, and NADPH) were prepared in $100 \mathrm{mM}$ hypoxic phosphate buffer (pH 7.4). $10 \mu \mathrm{M}$ of AZO-Flav was added into hypoxic phosphate buffer containing $50 \mu \mathrm{M}$ of NADPH and each interference.

For lysate preparation, HepG2 cells cultured in complete media (See Section 3.5.1) on a T-25 flask were washed twice with cold PBS. Subsequently, RIPA buffer (Thermo Scientific, Waltham, MA, USA) was added to the cells and the flask was kept on ice for 5 min, swirling occasionally. The cells were removed from the flask using a cell scraper, then transferred into a microcentrifuge tube. Collected cells were then centrifuged at $\sim 14,000 \times g$ for $15 \mathrm{~min}$. The supernatant was transferred to a new tube for further analysis.

For fluorescence experiments, all samples were incubated at $37^{\circ} \mathrm{C}$ for $5 \mathrm{~min}$ before adding AZO-Flav $(10 \mu \mathrm{M})$. The emission spectra were recorded at $\lambda_{\mathrm{ex}}=540 \mathrm{~nm}$ and $\lambda_{\mathrm{em}}=607 \mathrm{~nm}$.

\subsubsection{Limit of Detection (LOD) of AZO-Flav Reduction toward EcFldR}

$100 \mathrm{mM}$ hypoxic phosphate buffer containing various concentrations of $E c F l d R(0$, $0.25,0.5,1,1.5,2,3,4$, and $5 \mu \mathrm{M}$ ) and $50 \mu \mathrm{M}$ of NADPH was preincubated at $37^{\circ} \mathrm{C}$ for $5 \mathrm{~min}$. After that, AZO-Flav was added to the solution at a final concentration of $10 \mu \mathrm{M}$. The fluorescence intensity of the reduction product, Flav- $\mathbf{N H}_{2}$, was analyzed by a fluorescence spectrophotometer $\left(\lambda_{\mathrm{ex}}=540 \mathrm{~nm}\right.$ and $\left.\lambda_{\mathrm{em}}=607 \mathrm{~nm}\right)$.

\subsubsection{HPLC for AZO-Flav with EcFldR}

The reaction solutions were prepared in $100 \mathrm{mM}$ hypoxic phosphate buffer containing $2 \mu \mathrm{M}$ of $E c$ FldR and $50 \mu \mathrm{M}$ of NADPH; these were preincubated at $37{ }^{\circ} \mathrm{C}$ for $5 \mathrm{~min}$. AZO-Flav was then added to the final concentration of $10 \mu \mathrm{M}$ to initiate the reaction. The mixture was incubated for $5 \mathrm{~min}$. The reaction was quenched by adding $50 \%$ acetonitrile to precipitate EcFldR followed by centrifugation at 10,000 rpm for $5 \mathrm{~min}$ to remove the protein. The supernatant was analyzed by HPLC. Reverse phase HPLC analysis was performed on an Agilent HPLC 1100 using a column of ZORBAX Eclipse XDB-C18 (4.6 $\mathrm{mm} \times 150 \mathrm{~mm}, 5 \mu \mathrm{m}$ ID). The solvents were solvent A (water $+0.1 \%$ TFA) and solvent 
$\mathrm{B}$ (acentonitrile $+0.1 \%$ TFA). The linear gradient was as follows: $0 \mathrm{~min}: 100 \% \mathrm{~A} ; 2 \mathrm{~min}$ : 95\% A, 5\% B; 5 min: 85\% A, 15\% B; 10 min: 5\% A, 95\% B; $12 \min : 5 \%$ A, 95\% B; $14 \min$ : 95\% A, 5\% B; $16 \mathrm{~min}: 100 \% \mathrm{~A} ; 20 \mathrm{~min}: 100 \% \mathrm{~A}$. The flow rate was $1 \mathrm{~mL} / \mathrm{min}$. The analysis was monitored by a UV-Vis detector at a wavelength of $560 \mathrm{~nm}$.

\subsection{Cell Culture and Confocal Imaging}

\subsubsection{Cell Culture}

HepG2 (a human liver cancer cell line, purchased from ATCC) cells were cultured on a $75 \mathrm{~cm}^{3}$ culture flask in a complete medium, Dulbecco's Modified Eagle's Media (DMEM, Hyclone) supplemented with 10\% fetal bovine serum (FBS, Gibco) and 1\% penicillinstreptomycin (Corning). The cells were incubated at $37{ }^{\circ} \mathrm{C}$ in a humidified atmosphere containing $5 \% \mathrm{CO}_{2}$. Under hypoxia conditions, the cells were incubated in a hypoxia incubator chamber (STEMCELL Technologies Inc., Vancouver, BC, Canada).

\subsubsection{Cell Imaging}

HepG2 cells were seeded on an 8-well chambered coverglass (LabTek, Nunc) at $1 \times 10^{4}$ per well and incubated at $37^{\circ} \mathrm{C}$ for $24 \mathrm{~h}$. For time-dependent cellular uptake, the cells were incubated under normoxic (humidified 95\% air, 5\% $\mathrm{CO}_{2}$ atmosphere) and hypoxic $\left(5 \% \mathrm{pO}_{2}\right)$ conditions at $37^{\circ} \mathrm{C}$ for $12 \mathrm{~h}$. Subsequently, the cells were treated with $5 \mu \mathrm{M}$ of AZO-Flav (or Flav- $\mathbf{N H}_{2}$ ) in FBS-free DMEM for 0, 15, 30, and $60 \mathrm{~min}$. For dose dependent cellular uptake, the cells were treated with $0,5,10$, and $20 \mu \mathrm{M}$ of AZO-Flav and Flav-NH in FBS-free DMEM for $60 \mathrm{~min}$. After the incubation, the cells were washed with PBS buffer (0.01 M, pH 7.4) three times and treated with fresh media containing $1.0 \mu \mathrm{M}$ of Hoechst 33342 (Thermo Fisher Scientific) for $10 \mathrm{~min}$ before being imaged by a Laser Scanning Confocal Microscope (LSCM, Nikon A1Rsi). Laser sources were as follows: excitation: $561 \mathrm{~nm}$ and emission: $595 \mathrm{~nm} / 50 \mathrm{~nm}$ (for AZO-Flav or Flav-NH2), and excitation: $405 \mathrm{~nm}$ and emission: $450 \mathrm{~nm} / 50 \mathrm{~nm}$ (for Hoechst 33342) using a 60X oil immersion objective lens. Quantitative corrected total cell fluorescence data were quantified using ImageJ and represented the mean \pm SD (100 cells from three independent experiments, $n=3$ ).

\subsubsection{Hypoxia Inhibitory Effect}

HepG2 cells were seeded on an 8 -well chambered coverglass (LabTek, Nunc) at $1 \times 10^{4}$ per well and incubated at $37^{\circ} \mathrm{C}$ for $24 \mathrm{~h}$. Subsequently, the cells were treated with 0,100 , and $200 \mu \mathrm{M}$ of diphenyliodonium chloride (DPIC, TCI) and incubated under hypoxic $\left(5 \% \mathrm{pO}_{2}\right)$ conditions at $37^{\circ} \mathrm{C}$ for $12 \mathrm{~h}$. After incubation, the cells were treated with $5 \mu \mathrm{M}$ of AZO-Flav in FBS-free DMEM for $60 \mathrm{~min}$. Then, the cells were washed with PBS buffer (0.01 M, pH 7.4), stained with Hoechst 33342, and visualized under LSCM.

\subsubsection{Cell Viability Assay of AZO-Flav and Flav- $-\mathrm{NH}_{2}$}

HepG2 cells were seeded on a 96-well cell culture plate at approximately $7 \times 10^{3}$ cells per well and incubated for $24 \mathrm{~h}$. Cells were then treated with different concentrations of AZO-Flav and Flav- $\mathbf{N H}_{2}(0,2.5,5,10,20,30,40$, and $50 \mu \mathrm{M})$ for $24 \mathrm{~h}$. After incubation, the cells were washed with PBS (three times) before adding $25 \mu \mathrm{L}\left(0.5 \mathrm{mg} \mathrm{mL}^{-1}\right)$ of MTT reagent (methylthiazolyldiphenyltetrazolium bromide, Sigma-Aldrich) in 0.01 M PBS ( $\mathrm{pH}$ 7.4) for $3 \mathrm{~h}$. After supernatant removal, DMSO $(100 \mu \mathrm{L})$ was added to dissolve the formazan product which was detected at a wavelength of $560 \mathrm{~nm}$ using a microplate reader (BMG Labtech/SPECTROstar Nano).

\section{Conclusions}

AZO-Flav was successfully developed as a hypoxia-responsive probe. In an enzymecatalyzed reduction, AZO-Flav exhibited high selectivity and sensitivity towards an electron transfer process in the presence of the reductase and its cofactor, NADPH, with a limit of detection about $0.4 \mu \mathrm{M}$. The azo bond was cleaved via the enzymatic reaction to release the corresponding amine (Flav- $\left.\mathbf{N H}_{2}\right)$ that provided the strong fluorescence turn-on 
signal. The capability of AZO-Flav to detect hypoxia in cancer cells was confirmed by cell imaging experiments. Fluorescence intensities were found to increase up to 26-fold when hypoxic cells were incubated with AZO-Flav for $60 \mathrm{~min}$. Moreover, fluorescence signals from the hypoxic cells can be suppressed by the inhibition of the electron transfer process, suggesting the azo bond reduction of AZO-Flav is associated with reductase in the hypoxic tumor. Lastly, the detected fluorescence signals from the cell nuclei after hypoxic cells incubated with AZO-Flav confirmed the existing of the reduction product $\left(\mathbf{F l a v}-\mathbf{N H}_{\mathbf{2}}\right)$ inside the cells. Therefore, AZO-Flav showed great potential in its application toward in vivo hypoxia detection.

Supplementary Materials: The followings are available online. General procedure for the synthesis of AZO-Flav and Flav- $\mathrm{NH}_{2}$ and compound characterizations; Figure S1: Calibration curve of Flav$\mathbf{N H}_{2}\left(\lambda_{\mathrm{ex}}=540 \mathrm{~nm}\right.$ and $\left.\lambda_{\mathrm{em}}=607 \mathrm{~nm}\right)$; Figure S2: $\mathrm{pH}$ effect in $100 \mathrm{mM}$ phosphate buffer at $\mathrm{pH}=3,4$, $5,6,7,8,9,10$, and 11 with $\lambda_{\mathrm{ex}}=540 \mathrm{~nm}$ and $\lambda_{\mathrm{em}}=607 \mathrm{~nm}$. (a) $10 \mu \mathrm{M}$ of Flav- $\mathbf{N H}_{2}$ and (b) $10 \mu \mathrm{M}$ of AZO-Flav; Figure S3: SDS-PAGE analysis of purified EcFldR; Figure S4: HPLC analysis of the metabolism of AZO-Flav when reacted with EcFldR reductase. AZO-Flav $(10 \mu \mathrm{M})$ and NADPH $(50 \mu \mathrm{M})$ were treated with $E c$ FldR reductase $(2 \mu \mathrm{M})$ for $5 \mathrm{~min}$. HPLC profiles were detected by UV/Vis at $560 \mathrm{~nm}$; Figure S5: MTT assay of AZO-flav and Flav- $\mathbf{N H}_{\mathbf{2}}$ in HepG2 at different concentrations, incubated for $24 \mathrm{~h}$; Figure S6: Time-dependent cellular uptake of Flav- $\mathbf{N H}_{\mathbf{2}}$ incubated for $\mathbf{0}, \mathbf{1 5}, \mathbf{3 0}$, and $60 \mathrm{~min}$; Figure S7: Confocal images of AZO-Flav incubated with hypoxic HepG2 cells and colocalized with sub-organelle trackers. Table S1: Comparison of AZO-Flav with commercially available hypoxia detection probes; Table S2: Comparison of AZO-Flav with a reported protein-based sensor; Table S3: The structures and $\mathrm{O} 2$ responses of azo-based probes. Video files of imaging of cells (hypoxia and normoxia) incubated with AZO-Flav from 15-60 min; video recording of photobleaching behavior of the dye in hypoxic cells from $60-120 \mathrm{~min}$.

Author Contributions: Conceptualization: A.K.; data curation: T.P., S.W.-o., S.W., U.N., K.C., C.D. and R.-Y.L.; funding acquisition: A.K., M.S., R.-Y.L.; investigation: T.P., S.W.-o., S.W., U.N. and K.C.; methodology: A.K., R.-Y.L., S.W.-o. and T.P.; project administration: A.K.; resources: K.C., R.-Y.L., P.N. and M.S.; supervision: A.K., R.-Y.L., K.C. and M.S.; validation: S.W.-o., T.P. and A.K.; visualization: S.W.-O., T.P., S.W., K.C., U.N., C.D., R.-Y.L. and A.K.; writing—original draft production: T.P., S.W.-o., R.-Y.L. and A.K.; writing - review \& editing: all authors. All authors have read and agreed to the published version of the manuscript.

Funding: This work was supported by the Suranaree University of Technology (SUT) and by Thailand Science Research and Innovation (TSRI), the National Research Council of Thailand (N41A640150). A.K. and M.S. thank the Thailand Research Fund (TRF) under grant no. RTA6180007 and RYL thanks the National Research Council of Thailand (NRCT) under grant number NRCT/PS/132/2563 for financial support.

Data Availability Statement: Data are contained within the article or Supplementary Materials. The data set can be found via doi:10.6084/m9.figshare.15117108.

Conflicts of Interest: The authors declare no conflict of interest.

Sample Availability: Samples of AZO-Flav and Flav- $\mathrm{NH}_{2}$ are available from the authors.

\section{References}

1. Luo, S.; Liu, Y.; Wang, F.; Fei, Q.; Shi, B.; An, J.; Zhao, C.; Tung, C.-H. A fluorescent turn-on probe for visualizing lysosomes in hypoxic tumor cells. Analyst 2016, 141, 2879-2882. [CrossRef]

2. Wheeler, K.T.; Wang, L.-M.; A Wallen, C.; Childers, S.R.; Cline, J.M.; Keng, P.C.; Mach, R.H. Sigma-2 receptors as a biomarker of proliferation in solid tumours. Br. J. Cancer 2000, 82, 1223-1232. [CrossRef] [PubMed]

3. Höckel, M.; Vaupel, P. Tumor Hypoxia: Definitions and Current Clinical, Biologic, and Molecular Aspects. J. Natl. Cancer Inst. 2001, 93, 266-276. [CrossRef] [PubMed]

4. Al Tameemi, W.; Dale, T.P.; Al-Jumaily, R.M.K.; Forsyth, N.R. Hypoxia-Modified Cancer Cell Metabolism. Front. Cell Dev. Biol. 2019, 7, 4. [CrossRef]

5. Dutta, B.; Yan, R.; Lim, S.K.; Tam, J.P.; Sze, S.K. Quantitative Profiling of Chromatome Dynamics Reveals a Novel Role for HP1BP3 in Hypoxia-induced Oncogenesis. Mol. Cell. Proteom. 2014, 13, 3236-3249. [CrossRef]

6. Rademakers, S.E.; Span, P.; Kaanders, J.H.; Sweep, F.; Van Der Kogel, A.J.; Bussink, J. Molecular aspects of tumour hypoxia. Mol. Oncol. 2008, 2, 41-53. [CrossRef] [PubMed] 
7. Wang, C.; Zhang, S.; Huang, J.; Cui, L.; Hu, J.; Tan, S. Novel designed azo substituted semi-cyanine fluorescent probe for cytochrome P450 reductase detection and hypoxia imaging in cancer cells. RSC Adv. 2019, 9, 21572-21577. [CrossRef]

8. Cai, Q.; Yu, T.; Zhu, W.; Xu, Y.; Qian, X. A turn-on fluorescent probe for tumor hypoxia imaging in living cells. Chem. Commun. 2015, 51, 14739-14741. [CrossRef]

9. Kiyose, K.; Hanaoka, K.; Oushiki, D.; Nakamura, T.; Kajimura, M.; Suematsu, M.; Nishimatsu, H.; Yamane, T.; Terai, T.; Hirata, Y.; et al. Hypoxia-Sensitive Fluorescent Probes for in Vivo Real-Time Fluorescence Imaging of Acute Ischemia. J. Am. Chem. Soc. 2010, 132, 15846-15848. [CrossRef]

10. Luo, S.; Zou, R.; Wu, J.; Landry, M.P. A Probe for the Detection of Hypoxic Cancer Cells. ACS Sensors 2017, 2, 1139-1145. [CrossRef]

11. Kumari, R.; Sunil, D.; Ningthoujam, R.S.; Kumar, N.A. Azodyes as markers for tumor hypoxia imaging and therapy: An up-to-date review. Chem. Interactions 2019, 307, 91-104. [CrossRef] [PubMed]

12. Fradette, C.; Du Souich, P. Effect of hypoxia on cytochrome P450 activity and expression. Curr. Drug Metab. 2004, 5, 257-271. [CrossRef]

13. Patterson, A.; Saunders, M.P.; Chinje, E.C.; Talbot, D.C.; Harris, A.; Strafford, I.J. Overexpression of human NADPH:cytochrome c (P450) reductase confers enhanced sensitivity to both tirapazamine (SR 4233) and RSU 1069. Br. J. Cancer 1997, 76, $1338-1347$. [CrossRef] [PubMed]

14. Williams, K.J.; Cowen, R.L.; Stratford, I.J. Hypoxia and oxidative stress. Tumour hypoxia-therapeutic considerations. Breast Cancer Res. 2001, 3, 328-331. [CrossRef] [PubMed]

15. Wright, A.; Song, J.; Cravatt, B.F. A Suite of Activity-Based Probes for Human Cytochrome P450 Enzymes. J. Am. Chem. Soc. 2009, 131, 10692-10700. [CrossRef]

16. Huttunen, K.M.; Mähönen, N.; Raunio, H.; Rautio, J. Cytochrome P450-activated prodrugs: Targeted drug delivery. Curr. Med. Chem. 2008, 15, 2346-2365. [CrossRef]

17. Rodriguez-Antona, C.; Ingelmansundberg, M. Cytochrome P450 pharmacogenetics and cancer. Oncogene 2006, 25, 1679-1691. [CrossRef] [PubMed]

18. Scripture, C.D.; Sparreboom, A.; Figg, W.D. Modulation of cytochrome P450 activity: Implications for cancer therapy. Lancet Oncol. 2005, 6, 780-789. [CrossRef]

19. McFadyen, M.C.E.; Melvin, W.T.; I Murray, G. Cytochrome P450 enzymes: Novel options for cancer therapeutics. Mol. Cancer Ther. 2004, 3, 363-371.

20. Wu, J.; Guan, X.; Dai, Z.; He, R.; Ding, X.; Yang, L.; Ge, G. Molecular probes for human cytochrome P450 enzymes: Recent progress and future perspectives. Coord. Chem. Rev. 2021, 427, 213600. [CrossRef]

21. Feng, L.; Ning, J.; Tian, X.; Wang, C.; Yu, Z.; Huo, X.; Xie, T.; Zhang, B.; James, T.D.; Ma, X. Fluorescent probes for the detection and imaging of Cytochrome P450. Coord. Chem. Rev. 2021, 437, 213740. [CrossRef]

22. Piao, W.; Tsuda, S.; Tanaka, Y.; Maeda, S.; Liu, F.; Takahashi, S.; Kushida, Y.; Komatsu, T.; Ueno, T.; Terai, T.; et al. Development of azo-based fluorescent probes to detect different levels of hypoxia. Angew. Chem. Int. Ed. Engl. 2013, 52, 13028-13032. [CrossRef]

23. Wilson, W.R.; Hay, M. Targeting hypoxia in cancer therapy. Nat. Rev. Cancer 2011, 11, 393-410. [CrossRef] [PubMed]

24. Cui, L.; Shi, Y.; Zhang, S.; Yan, L.; Zhang, H.; Tian, Z.; Gu, Y.; Guo, T.; Huang, J. A NIR turn-on fluorescent probe applied in cytochrome P450 reductase detection and hypoxia imaging in tumor cells. Dye. Pigment. 2017, 139, 587-592. [CrossRef]

25. Pina, F.; Petrov, V.; Laia, C.A.T. Photochromism of flavylium systems. An overview of a versatile multistate system. Dyes Pigm. 2012, 92, 877-889. [CrossRef]

26. Pina, F.; Melo, M.J.; Laia, C.; Parola, A.J.; Lima, J.C. Chemistry and applications of flavylium compounds: A handful of colours. Chem. Soc. Rev. 2012, 41, 869-908. [CrossRef] [PubMed]

27. Kim, S.; Yoon, J.; Yoon, S.; Lee, M. Ratiometric Fluorescence Assay for Nitroreductase Activity: Locked-Flavylium Fluorophore as a NTR-Sensitive Molecular Probe. Molecules 2021, 26, 1088. [CrossRef] [PubMed]

28. Gong, X.; Yang, X.-F.; Zhong, Y.; Chen, H.; Li, Z. A flavylium-based turn-on fluorescent probe for imaging hydrogen polysulfides in living cells. RSC Adv. 2016, 6, 88519-88525. [CrossRef]

29. Bandara, H.M.; Burdette, S.C. Photoisomerization in different classes of azobenzene. Chem. Soc. Rev. 2012, 41, 1809-1825. [CrossRef]

30. Chevalier, A.; Renard, P.-Y.; Romieu, A. Azo-Based Fluorogenic Probes for Biosensing and Bioimaging: Recent Advances and Upcoming Challenges. Chem. Asian J. 2017, 12, 2008-2028. [CrossRef]

31. Ren, T.-B.; Xu, W.; Jin, F.; Cheng, D.; Zhang, L.; Yuan, L.; Zhang, X. Rational Engineering of Bioinspired Anthocyanidin Fluorophores with Excellent Two-Photon Properties for Sensing and Imaging. Anal. Chem. 2017, 89, 11427-11434. [CrossRef]

32. Thews, O.; Riemann, A. Tumor $\mathrm{pH}$ and metastasis: A malignant process beyond hypoxia. Cancer Metastasis Rev. 2019, 38, 113-129. [CrossRef]

33. Jenkins, C.M.; Waterman, M.R. NADPH-Flavodoxin Reductase and Flavodoxin from Escherichia coli: Characteristics as a Soluble Microsomal P450 Reductase. Biochemistry 1998, 37, 6106-6113. [CrossRef] [PubMed]

34. Jenkins, C.M.; Waterman, M.R. Flavodoxin and NADPH-flavodoxin reductase from Escherichia coli support bovine cytochrome P450c17 hydroxylase activities. J. Biol. Chem. 1994, 269, 27401-27408. [CrossRef]

35. Jenkins, C.M.; Waterman, M.R. Flavodoxin As A Model for The P450-Interacting Domain of Nadph Cytochrome P450 Reductase. Drug Metab. Rev. 1999, 31, 195-203. [CrossRef] [PubMed] 
36. Begleiter, A.; Leith, M.K.; Patel, D.; Hasinoff, B.B. Role of NADPH cytochrome P450 reductase in activation of RH1. Cancer Chemother. Pharmacol. 2007, 60, 713-723. [CrossRef]

37. Kleniewska, P.; Piechota-Polanczyk, A.; Skibska, B.; Goraca, A. The NADPH Oxidase Family and its Inhibitors. Arch. Immunol. Ther. Exp. 2012, 60, 277-294. [CrossRef]

38. Panday, A.; Sahoo, M.; Osorio, D.; Batra, S. NADPH oxidases: An overview from structure to innate immunity-associated pathologies. Cell. Mol. Immunol. 2015, 12, 5-23. [CrossRef] [PubMed]

39. Crnolatac, I.; Giestas, L.; Horvat, G.; Parola, A.J.; Piantanida, I. Flavylium Dye as pH-Tunable Fluorescent and CD Probe for Double-Stranded DNA and RNA. Chemosensors 2020, 8, 129. [CrossRef]

40. Sarma, A.D.; Sharma, R. Anthocyanin-DNA copigmentation complex: Mutual protection against oxidative damage. Phytochemistry 1999, 52, 1313-1318. [CrossRef]

41. Koch, C.J. [1] Measurement of absolute oxygen levels in cells and tissues using oxygen sensors and 2-nitroimidazole EF5. Methods Enzymol. 2002, 352, 3-31. [CrossRef]

42. Iglesias, P.; Penas, C.; Barral-Cagiao, L.; Pazos, E.; Costoya, J.A. A Bio-inspired Hypoxia Sensor using HIF1a-Oxygen-Dependent Degradation Domain. Sci. Rep. 2019, 9, 7117. [CrossRef] [PubMed]

43. Uddin, I.; Evans, S.M.; Craft, J.R.; Marnett, L.J.; Uddin, J.; Jayagopal, A. Applications of Azo-Based Probes for Imaging Retinal Hypoxia. ACS Med. Chem. Lett. 2015, 6, 445-449. [CrossRef]

44. Tian, Y.; Li, Y.; Jiang, W.-L.; Zhou, D.-Y.; Fei, J.; Li, C.-Y. In-Situ Imaging of Azoreductase Activity in the Acute and Chronic Ulcerative Colitis Mice by a Near-Infrared Fluorescent Probe. Anal. Chem. 2019, 91, 10901-10907. [CrossRef] [PubMed]

45. Zhou, Y.; Maiti, M.; Sharma, A.; Won, M.; Yu, L.; Miao, L.X.; Shin, J.; Podder, A.; Bobba, K.N.; Han, J.; et al. Azo-based small molecular hypoxia responsive theranostic for tumor-specific imaging and therapy. J. Control. Release 2018, 288, 14-22. [CrossRef] [PubMed]

46. Chevalier, A.; Piao, W.; Hanaoka, K.; Nagano, T.; Renard, P.-Y.; Romieu, A. Azobenzene-caged sulforhodamine dyes: A novel class of 'turn-on' reactive probes for hypoxic tumor cell imaging. Methods Appl. Fluoresc. 2015, 3, 44004. [CrossRef]

47. Huang, J.; Wu, Y.; Zeng, F.; Wu, S. An Activatable Near-Infrared Chromophore for Multispectral Optoacoustic Imaging of Tumor Hypoxia and for Tumor Inhibition. Theranostics 2019, 9, 7313-7324. [CrossRef] [PubMed] 